\title{
Effect of Soil Solarisation for the Control Soil Born Pathogen S. rolfsii Causing Stem Rot of Chilli (Capsicum annuum L.)
}

\author{
Prem Naresh", Ved Ratan, Virendra Kumar and Upesh Kumar \\ Department of Plant Pathology, C. S. Azad University of Agriculture and Technology, \\ Kanpur-208002, India \\ *Corresponding author
}

\section{A B S T R A C T}

\begin{tabular}{|l|}
\hline Ke y w or d s \\
Chilli (Capsicum \\
annuum L.) \\
$\begin{array}{l}\text { Sclerosium rolfsii } \\
\text { Sacc, Soil } \\
\text { solarisation and } \\
\text { Stem rot. }\end{array}$ \\
\hline Article Info \\
\hline $\begin{array}{l}\text { Accepted: } \\
\text { 29 September 2017 } \\
\text { Available Online: } \\
\text { 10 October 2017 }\end{array}$ \\
\hline \hline
\end{tabular}

Afield experiment was conducted to study, the effect of soil solarisation for the control of $S$. rofsii pathogen causing stem rot of chilli. Solarisation is a covering the soil with transparent polythene sheet (400 gauges) for 6 week during hot summer months (May and June) showed an increase in the soil temperature (up to $4-6^{\circ} \mathrm{C}$ ) and conservation of moisture (5\%) when compare to unsolarised plot(as control). In a field experiment naturally infected soil with stem rot of chilli, with ten replication carried out during 200809, 2009-10 and found that a significant reduction disease incidence was recorded in solarised plot as against non solarised plot (control).The average soil temperature (50C) were increases $(41.8-46.40 \mathrm{C})$ which is lethal to soil pathogen and decreases disease incidence. A pot experiment were also conducted in net house during 2009-10 sowing 25 seeds per $30 \mathrm{~cm}$.diameter earthen pots having four treatment and three replications and found maximum disease incidence (100\%) in control (uncovered with polythene and nonirrigated as compared to covered with polythene and irrigated pots(20\%).

\section{Introduction}

The chilli (Capsicum annuum L.) also known as Mircha is an important spice and vegetable crop belonging to the family Solanaceae. In India, chillis are grown in almost all the states of the country.

In India, area, production and productivity of chilli were 767.23 million ha. 1202.94 million tones and $1.6 \mathrm{mt} / \mathrm{ha}$, respectively (Parthasarathy and Kandiannan, 2010).

There are so many diseases responsible for lowering down the production and productivity of chilli. Among fungal diseases, stem rot of chilli caused by Sclerosium rolfsii Sacc. is an important disease in India.
This is the first report of S. rolfsii causing collar rot in chilli from Gujarat (Lukose et al., 2003). The disease is also known as foot rot/ Southern blight/ white stem rot/ stem rot in different places of the country. Chilli is highly susceptible to the disease and causing 50 to 60 per cent seedling mortality (Lukose et al., 2003).

The severe stem rot of chilli causing $30-40 \%$ seedling rot was observed in a 2.0 ha at farmer's field in Saurashtra (Gujrat) India (Bhoraniya et al., 2002). It is a destructive plant pathogen with an almost unlimited host range. In chilli crop the yield product is the fruit which directly consumed by people. 
Hence chemical controls are not recommended as the presence of residues in green fruit may leads health hazards. Pathogen is soil born in nature and disease inoculums increase in proportion from year to year. Therefore soil solarisation was required for the controlling soil borne pathogen. Soil solarisation by mulching soil surface with plastic film during summer months raises soil temperature to a lethal level. This method has been successfully employed in eliminating several soil borne pathogens. Management of disease through this, environmentally safe method is present day need. The appropriate management of this disease before field condition was essential in laboratory and pot culture. Keeping in view importance of disease, present investigation was under taken for find out the effect of soil solarization in management against fungus $S$. rolfsii causing stem rot in chilli.

\section{Materials and Methods}

\section{Soil solarisation (In field)}

In order to find out the effect of soil solarisation, a field experiment in naturally infested soil with stem rot of chilli with ten replications were carried out during 2008-09 and $2009-10$ to study the effect of soil solarisation on stem rot in chilli. The experiment was conducted during hot summer month (May to June). The soil of experimental field was sandy loam and treatments comprised of solarised and nonsolarised (as control) plot with the size $4.0 \mathrm{x}$ $2.50 \mathrm{~m}^{2}$. For solarisation, plots were covered with clear transparent polythene sheet (400 gauges) for five week in the month of May and June (from $20^{\text {th }}$ May to $20^{\text {th }}$ June in both the year) fallowing the procedure of Chauhan et al., (1988). All the plots were uniformly irrigated to field capacity one day prior to imposing polythene mulch in treatment. Randomized block design was applied for comparison between solarised and unsolarised (control) plots $(8 \times 3 \mathrm{M})$ each treatment was replicated thrice. Soil temperature of solarised and unsolarised plots during solarisation period was recorded at $1400 \mathrm{~h}(2.00 \mathrm{pm})$ at a depth of 5 and $20 \mathrm{~cm}$ using soil thermometer. After expire of date of solarisation, polythene sheets were removed and 25-30 days old chilli seedlings were planted. The data on disease incidence were recorded after two months of planting (Plate-3).

\section{In pots}

The experiment was conducted in the net house, Department of Plant Pathology during 2009-10. Earthen pots having diameter of 30 $\mathrm{cm}$. were filled with $5 \mathrm{~kg}$ moist solarised soil. Sclerotia $(5.0 \mathrm{~g})$ were evenly distributed below the two $\mathrm{cm}$. soil layer. Four treatments i.e. covered with polythene + irrigated, uncovered with polythene + irrigated, covered with polythene + none irrigated and uncovered with polythene + none irrigated with three replications were taken. Covered with polythene and uncovered with polythene irrigated treatments were given sufficient water before adding the inoculums.

The pots were tightly wrapped with clear transparent polythene sheet (400 gauges) and solarised for five weeks from May to June. Pots were directly exposed to sun light from 10.0 am to $4.00 \mathrm{pm}$ every day. Temperature of solarised and non solarised pots were recorded at depth of $15 \mathrm{~cm}$ along with day temperature(maximum) after every $24 \mathrm{hrs}$ at 2 p.m. for 40 days between May to June 200910. Sheet from pots was removed after completion of period of solarisaton. Healthy 25-30 days old seedlings of chilli were planted in the month of July and 5-10 plants in each pot were maintained. Observations on disease incidence were recorded after 45 days of planting. The following formula was used for calculating disease incidence. 
No. of diseased plants in sub plot Disease incidence

(Stem rot) $\%=$ $\mathrm{x} 100$

Total No. of plants in sub plot

\section{Result and Discussion}

Effect of soil solarisation on disease severity (In field)

It is clearly indicated from the data presented in Table-1 and Figure 1 that a significant reduction in disease incidence was recorded in solarised plots as against non-solarised plots. Average soil temperature at $5 \mathrm{~cm}$ and $20 \mathrm{~cm}$ was $46.40^{\circ} \mathrm{C}$ and $41.80^{\circ} \mathrm{C}$ respectively and average disease incidence was 9 per cent and 66 per cent on solarised and non solarised plots respectively.

The plots covered with polythene had markedly higher average temperature (46.40 $\left.{ }^{0} \mathrm{C}\right)$ as compared to non- covered plots $\left(41.80^{\circ} \mathrm{C}\right)$. The temperature more than $46.40^{\circ}$ $\mathrm{C}$ is in most of the causes lethal to maximum soil born pathogen. Rao and Mathur et al., (2003) also reported that solar heating by polythene was effective for the control of collar rot of chilli caused by Sclerotium rolfsii Sacc.

Rao and Maity (2003) evaluate solar heating by polyethylene mulching for the control of collar rot of chilli caused by Sclerotium rolfsii Sacc. The total elimination in the viability of sclerotial population to the total elimination in the viability of sclerotial population at $5 \mathrm{~cm}$ depth after 14 and at $10 \mathrm{~cm}$ depth after 21 days, while $56.67 \%$ loss in viability was observed at $15 \mathrm{~cm}$ depth after 21days. The highest temperature recorded during the experimentation was $51.4{ }^{\circ} \mathrm{C}, 48.9^{\circ} \mathrm{C}$ and 45.9 ${ }^{0} \mathrm{C}$ at 5,10 , and $15 \mathrm{~cm}$ depth, respectively while at same days ambient temperature was $37.4^{0} \mathrm{C}$.

Raj, et al., (1997) also repoted that soil solarisation with transparent polythen multch was effective to control damping off pathogen of different vegetable crops in the nursery. Nursery bed soil was flood irrigated and then covered with transparent polythene sheet for 40 days. Mulching with polythene resulted in 13.50C higher temp. Killed the Pythium sp. and Fusarium spp. and recorded 18.3 to $42.0 \%$ higher seed germination, lower incidence.

Table.1 Effect of soil solarisation on stem rot under field condition

\begin{tabular}{|c|c|c|c|c|c|c|}
\hline \multirow[t]{2}{*}{ Treatment } & \multirow{2}{*}{$\begin{array}{l}\text { Avg. Soil temp. } \\
\left(\max { }^{0} \mathrm{C}\right) \text { at } 5 \& \\
20 \mathrm{~cm} . \text { depth }\end{array}$} & \multirow[t]{2}{*}{$\begin{array}{c}\text { Average air } \\
\text { Temp. }^{0} \mathrm{C}\end{array}$} & \multicolumn{2}{|c|}{$\begin{array}{c}\text { Disease incidence } \\
(\%)\end{array}$} & \multirow{2}{*}{$\begin{array}{c}\text { Average } \\
\text { disease } \\
\text { incidenc } \\
\mathrm{e}(\%)\end{array}$} & \multirow{2}{*}{$\begin{array}{c}\% \\
\text { reduction } \\
\text { in disease } \\
\text { incidence }\end{array}$} \\
\hline & & & $2009-10$ & $2010-11$ & & \\
\hline Solarised & 46.40 & 38.90 & $\begin{array}{c}8.18 \\
(16.57)\end{array}$ & $\begin{array}{c}9.2 \\
(17.64)\end{array}$ & 9 & 86.36 \\
\hline $\begin{array}{c}\text { Non- } \\
\text { solarised }\end{array}$ & 41.80 & - & $\begin{array}{c}63 \\
(52.57)\end{array}$ & $\begin{array}{c}72 \\
(58.07)\end{array}$ & 66 & - \\
\hline \multicolumn{3}{|l|}{$\mathrm{CD}$ at $0.5 \%$} & 3.52 & 2.22 & & \\
\hline \multicolumn{3}{|l|}{ S.E. m. } & 1.08 & 0.68 & & \\
\hline
\end{tabular}


Table.2 Effect of soil solarization on stem rot under glass house

\begin{tabular}{|l|c|c|c|c|}
\hline \multicolumn{1}{|c|}{ Treatment } & $\begin{array}{c}\text { No. of seeds } \\
\text { sown/pot }\end{array}$ & $\begin{array}{c}\text { No. of } \\
\text { affected } \\
\text { plants }\end{array}$ & $\begin{array}{c}\text { Disease } \\
\text { incidence } \\
(\mathbf{\%})\end{array}$ & $\begin{array}{c}\text { \% reduction in } \\
\text { disease } \\
\text { incidence }\end{array}$ \\
\hline Covered with Polythene + irrigated & 25 & 03 & $12(20.22)$ & 88 \\
\hline Without covered polythene + irrigated & 25 & 20 & $84(66.47)$ & 16 \\
\hline Covered with Polythene + none irrigated & 25 & 06 & $24(29.31)$ & 76 \\
\hline Without covered polythene + none irrigated(control) & 25 & 25 & $100(86.05)$ & - \\
\hline C.D. at 0.5\% & & 4.27 & \multicolumn{3}{|c|}{} \\
SE. m. & & 1.41 & & \\
\hline
\end{tabular}

Fig.1 Effect of soil solarisation on stem rot under field condition

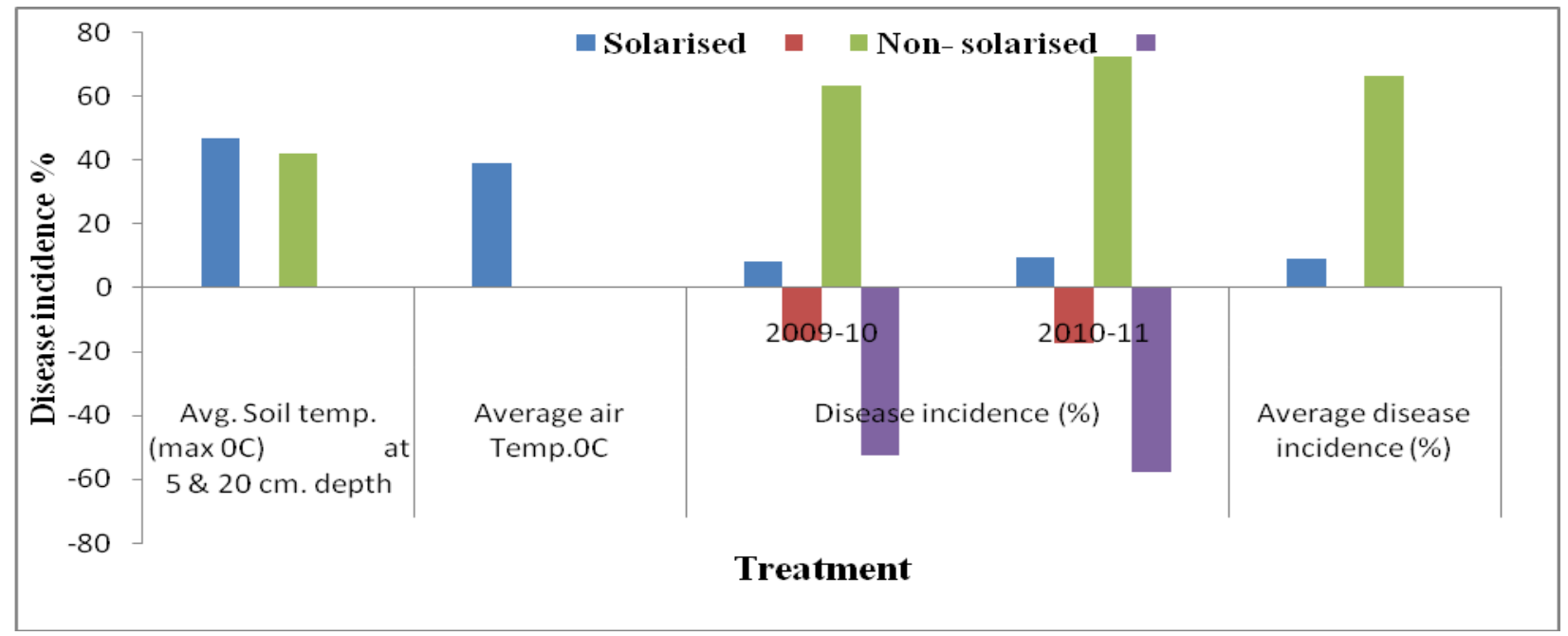

Fig.2 Effect of soil solarization on stem rot under glass house

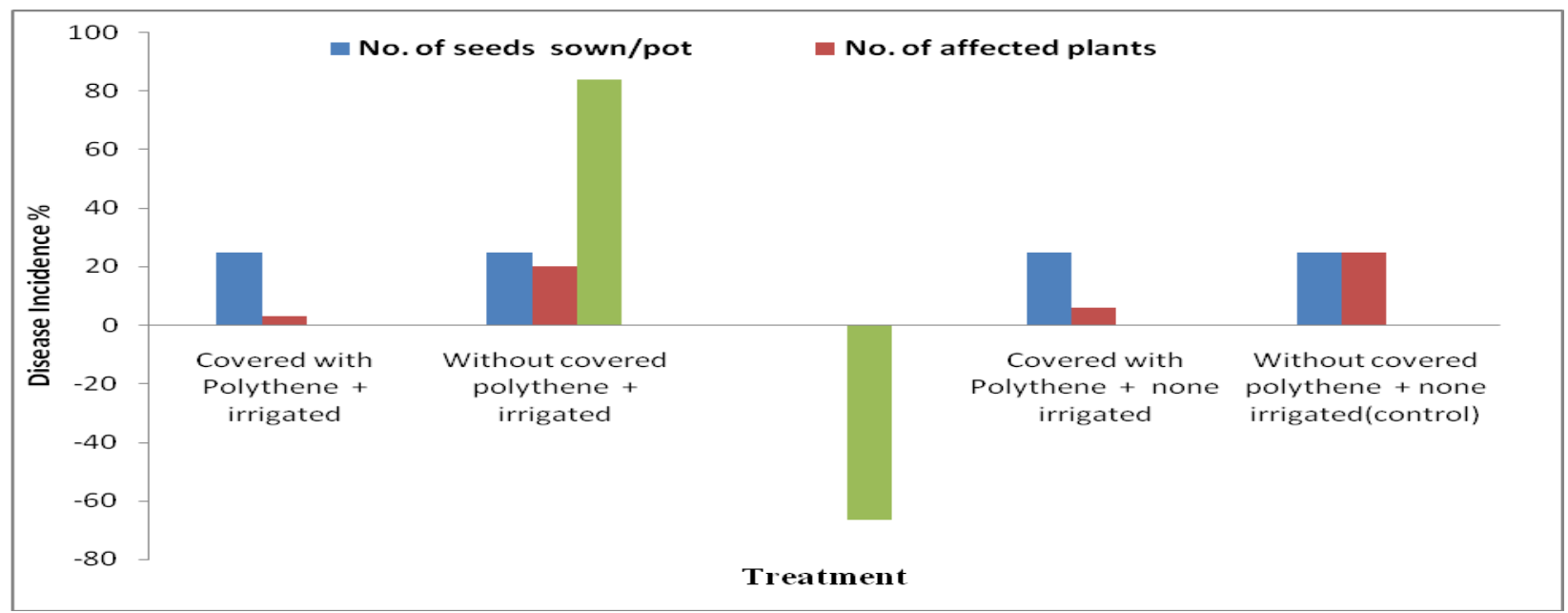

\section{In pots condition}

The data presented in Table 2 and Figure 2 indicated that the pots covered with polythene and irrigated showed 88 per cent reduction in disease incidence. However it was 76 per cent when pots were not irrigated. In non-covered and non-irrigated pots 100 per cent disease was 
observed as 84 per cent disease was noticed in non-poly irrigated plots. Soil moisture was greatly affected in the sensitivity of resting structures of pathogen.

Tiwari, et al., (1997b) also found that pots covered with transparent polythene sheet attained markedly higher temperatures compared with the uncovered control. The average soil temperature exceeded $50{ }^{\circ} \mathrm{C}$ and 45 ${ }^{\circ} \mathrm{C}$, at 5 and $10 \mathrm{~cm}$ depths, respectively in solarized soils. Solarizations significantly decrease diseases in solarized pots were completely free from sclerotial root rot, when sclerotia were placed at $5 \mathrm{~cm}$. depth. The chickpea crop was also disease free where sclerotia were placed at 5 and $10 \mathrm{~cm}$. depth in pots with moist soil.

Deshpande et al., (2007) also reported that all the betel vine cuttings planted in solarised pots were found free from collar rot (S.rolfsii) disease (mortality 0.00 per cent). Even then, in case of five days solarisation, all cuttings were found free from collar rot infection. Tiwari, et al., (1997b) who has found that pots covered with transparent polythene sheet attained markedly higher temperature as compared with the uncovered which are lethal to pathogen.

\section{References}

Bhoraniya, M.F., Khandar, R.R. and Khunti, J.P. 2002. Estimation of oxalic acid in chilli infected with Sclerotium rolfsii, $\mathrm{Pl}$. Dis. Res., 17(2): 325.

Chauhan, Y.S., Nene, Y.L., Johansen, C., Haware, M.P., Saxsena, N.P., Singh, S., Sharma, S.B., Sahrawat, K.L., Burford, J.R., Rupela, O.P., Kumar, Rao, J.V.D.K. and Sithanantham, S. 1988. Effect of soil solarization on pigeonpea and chickpea. Research Bulletin II, ICRISAT. Patancheru, $16 \mathrm{pp}$.

Deshpande, A. L., and Tiwari, R.K.S. 1991. Effect of solarisation on sclerotia of Sclerotium rolfsii causing collar rot in betele vine. Indian Phytopath. 44(3):353355.

Kochi, G.K., 2005. The Hindu business line: chilli export touch all-time high. The Hindu group of Publications (www.indianspices.com/html/S2200ssp.ht $\mathrm{m})$, pp.1-3.

Lukose, Clara M., Kadvani, D.L. and Dangaria, C.J. 2003. Bulb and stem rot of garlic and chili. Indian Phytopath, 56(2):237.

Parthasarathy, V.A., and Kandiannan, K. 2010. Bio diversity of different spices. The Hindu Survey of Indian Agriculture, Chennai p37.

Raj, Harender, Bharadwasj, M.L. and Sharma, N.K. 1997.Soil solarisatio for the control of damping off of different vegetable crops in the nursery. Indian Phytopath. 50(4):524-528.

Rao, J.S.P., and S.S. Maity 2002. Solar heating by polyethylene mulching for the control of collar rot of chilli caused by Sclerotium rolfsii Sacc. J. Mycopath. Res., 41:2,193196.9 ref.

Reddy, T.B.M., M.R, Govindappa, A.S. Padmaj and K.S. Shankarappa, 2007. Influence of soil solarization on Yields of Groundnut and tomato. Environment and Ecology. Colcatta, India. 25(4):734-38.

Tiwari, R. K.S., Parkhar, S. S. and Chaure, N.K. 1997b. Soil solarization for the control of Sclerotium rolfsii causing sclerotial root rot of chickpea Indian J. Pl. Protect, 25 (2):142-45.

\section{How to cite this article:}

Prem Naresh, Ved Ratan, Virendra Kumar and Upesh Kumar. 2017. Effect of Soil Solarisation for the Control Soil Born Pathogen S. rolfsii Causing Stem Rot of Chilli (Capsicum annuum L.). Int.J.Curr.Microbiol.App.Sci. 6(10): 4913-4917. doi: https://doi.org/10.20546/ijcmas.2017.610.462 